\title{
Keskustelua
}

\section{AVOIN KORKEAKOULU KOULUTUKSEN UUDISTAMISSUUNNITELMISSA}

\begin{abstract}
A voimen korkeakoulun opetukseen etsiytyvien motiivit A poikkeavat koulunpenkiltä tulevien motiiveista. He tulevat usein hakemaan arvosanojen ja todistusten sijasta merkityksiä, ratkaisuja ongelmiin, korkeakoulusivistystä sanan alkuperäisessä, itsearvoisessa merkityksessä. Korkeakoulujen tuotekehittely ja organisaatio eivät kuitenkaan ole seuranneet tätä kehitystä, kirjoittaa Reijo Raivola kannanotossaan.
\end{abstract}

\begin{abstract}
A ikuiskoulutukseen vaikuttavat samat muutospaineet kuin A koulujärjestelmäänkin lisättynä koulujärjestelmän kehityksen aiheuttamalla paineella. Tällaisina voisi mainita yhteiskunnan nopean poliittisen, taloudellisen ja sosiaalisen muutoksen, jolla tavallisesti on perusteltu ammatillisen täydennys- ja uudelleenkoulutuksen tarvetta. Myös peruskoulutuksen tason nousu nostaa korkea-asteen täydennyskoulutuksen tarvetta.
\end{abstract}

M utta yleisen muutoksen aiheuttamaa riittämättömyyttä voidaan tarkastella perinteisen funktionalistisen näkökulman lisäksi fenomenologisen elämismaailman problematiikkana. Ihmisen perusolemukseen on kuulunut pyrkimys pysyvyyteen, mikä takaa psyykkisen turvallisuudentunteen. Tunteehan ihminen silloin voivansa ennakoida tapahtuvaa ja näin hallitsevansa ympäristöään. Kun nyt jopa yhteiskunnan makrorakenteet jäsentyvät uudelleen, ihminen menettää ne majakat ja itsestäänselvyydet, joiden varassa hän on elämäänsä ohjannut. Arvot kuluvat ja arvojärjestelmätkin romahtavat. Anomiakäsiteellä on taas analyyttista selitysvoimaa! Koheesion palauttamiseksi tarvitaan siis uudenlaista nomosta rakentavaa toimintaa. Esimerkiksi korkeakoulujen ammatillista perus- ja täydennyskoulutusta ei voida johtaa pelkästään työn teknisistä vaatimuksista ja työorganisaatioista, vaan niiden on rakennuttava systeemiympäristöstä, kokonaisyhteiskunnasta ja ihmisestä itsestään.

Kuitenkin varsinkin yhteiskuntatieteellinen 46 korkeakouluopetus on ollut lähestymistavaltaan perinteisesti kriittisen analyyttistä. Se repii hajalle olemassa olevat instituutiot tarjoamatta tilalle uutta synteesiä. Kunkin koulutusideologia tietenkin määrää, millaisena se korkeakoulutuksen tehtävän näkee: tulisiko sen antaa paljaaksi rïsuttuja aineksia elämän rakennuspuiksi vai tarjota tukea elämän projektin määrittelemiseksi.

Moni avoimen korkeakoulun opiskelija on lähtenyt mukaan ratkaistaakseen henkilökohtaisen kriisinsä osallistumisen ja opiskelun avulla. En ole lainkaan varma, että raa'an analyyttinen ote rakentaa tällaisen opiskelijan persoonaa. Kysymys kuuluukin: onko ja pitäisikö avoimen korkeakoulun opetuksen myös kasvattaa tietoisesti?

Toisena voimakkaana muutostekijänä on yleiseurooppalainen demografinen kehitys. Väestö ikääntyy, ja määrällisesti muuttuva ikäluokkien suhde romuttaa kolmivaiheisen elämänkaariajattelun. Kuitenkin nuoruusiän peruskoulutus on pitenemistään pidentynyt, ja kouluoppimisen traditionaaliset mallit hallitsevat aikuiskoulutustakin. 
Esimerkiksi avoimen korkeakoulun opetussuunnitelmat seuraavat tarkoin ainelaitosten suunnitelmia, mitä tietenkin saavutusten legitimoinnin kannalta on pidetty elintärkeänä. Mutta tämän mallin seuraaminen estää avoimen korkeakoulun avoimuuden: se jää paljolti aikaan ja paikkaan sidotuksi, mikä kysynnän ylittäessä tarjonnan saa aikaan moniportaista karsintaa.

Yrittämistä karsiva tai jatkosta poispudottava avoin korkeakoulu on aikamoinen käsitteellinen paradoksi. Kuulusteluaikataulut, aikarajat ja tiedekuntaopiskelijan mukaan laaditut kurssivaatimukset saavat aikaan opiskelijoiden itsevalintaa.

EY:n komissio arvioi, että jäsenmaiden aktiiviväestöstä 80 prosenttia ei vapaaehtoinen täydennyskoulutus kiinnosta. (Siis pelkkä tarjonta ei riitä. Tarvitaan myös hakevaa toimintaa. Vrt. LO Ruotsissa 60-luvulta alkaen.) Lisäksi koulutuksen kuluessa tapahtuu runsaasti defensiivistä poisvalintaa, keskeyttämistä. Tulevaisuuden tehokkuusindikaattoreista keskeiseksi muodostuneekin tavoitteiseen päässeiden määrän suhde opintokokonaisuuden aloittaneiden määrään. Tavoitteet vain aikuisopiskelijalla vaihtelevat. Kaikilla tavoitteena ei alunperin ole ollutkaan koko tarjottu kokonaisuus.

$\mathrm{O}$ leellista on myös, että vanhamuotoisen korkeakoulutuksen kysyntä laskee väistämättä ikäluokkien pienemisen vuoksi. Samaan suuntaan vaikuttaa myös työvoiman uustarjonnan lasku. Konfliktiteoreettinen näkemys koulutuksen ja työn suhteista näkee koulutuksen paljolti työvoiman tarjontajonon muodon säätelijänä. Tarjonnan niukkuuden aikana jonoa ei synny. Tapahtuu todellista pikakvalifioitumista: hyvän yleissivistyksen saanut pätevöityy teknisesti työn ohessa.

Tällaisen uuden polven työntekijän koulutustarve ei kuitenkaan mitätöidy tuotantoelämän lyhytaikaisiin vaatimuksiin. Ammattien kehittämisen ja työssä kehittymisen varmistamiseksi tarvitaan perspektiiviä avartavaa ja teoreettista ymmärrystä lisäävää korkean asteen koulutusta. Useimmissa teollistuneissa maissa korkeakoulupopulaatio onkin muuttunut radikaasti. Se on vanhempaa, se käy työssä, se tulee usein yhteiskunnan marginaaliryhmistä ja elämänkokemukset ovat koulineet sen itsevarmaksi.

Monella on epämiellyttäviä koulukokemuksia. Sen koulutusmotiivit poikkeavat koulunpenkiltä tulevien motiiveista. Usein se näet tulee hakemaan arvosanojen ja todistusten sijasta merkityksiä, ratkaisuja ongelmiin, korkeakoulusivistystä sanan alkuperäisessä, itsearvoisessa merkitykses- sä. Korkeakoulujen tuotekehittely ja organisaatio eivät kuitenkaan ole seuranneet tätä kehitystä.

Demografinen muutos vaikuttaa myös väistämättä koulutusorganisaation rakenteeseen. Voimakkaasti koulutusasteisiin ja -aloihin, muodolliseen ja epämuodolliseen koulutuksen jakautunut toiminta käy resurssien ohentuessa kestämättömäksi. Tarjontakilpailu alkaa saada dysfunktionaalisia muotoja. Tarjontaa joudutaan sekä inhimillisten että aineellisten resurssien puuttuessa järkeistämään ts. integroimaan horisontaalisesti ja vertikaalisesti ja jopa supistamaan. Ei ole taloudellisesti mahdollista eikä toiminnallisesti mielekästä, että jokainen vakiintunut koulutusmuoto hankkisi omat päätoimiset opettajavoimat. Esimerkiksi avoin korkeakoulu tullee käyttämään lisääntyvässä määrin tiedelaitoksista vapautuvaa opetusvoimaa, mutta myös palaamaan vanhaan professionaaliseen ideaaliin, jossa professio työnsä ohessa tai oikeammin suoraan työhön sisältyen kouluttaa seuraajansa. Vakavasti on myös tutkittava dosenttien ja jatko-opiskelijoiden käyttöä avoimen korkeakoulun tarpeisiin.

$\mathrm{O}$ n selvää, että perinteinen institutionaalinen koulutus ei selviä muuttumattomana tulevista tehtävistään. Koulutuksen on avauduttava ja yhteiskunnallistuttava. Muutos näkyy jo terminologiassa, esimerkiksi jatkuvan koulutuksen korostamisesta on siirrytty korostamaan elinikäistä oppimista. Harvemmin muutos vielä näkyy oppimisen organisoinnin tasolla. Tosin Brittein saarilla on toistakymmentä vuotta ollut toiminnassa Open College ja muutaman vuoden myös Open Tech ison veljen, avoimen yliopiston rinnalla.

Meillä Turun integraatiokokeilu, Jyväskylän etäopetustoiminta ja Tampereen tutkintotavoitteiset pätevöittämiskurssit ja poikkitieteiset täydennyskoulutuskokeilut (työtiede) edustavat uutta suuntausta. Koulutus on informaatioteknologisesti yhteiskunnan heikoimmin kehittynyt sektori. Monin paikoin etäopetus toimii vielä ensimmäisen polven kirjeopiskeluna tai toisen polven toimintana, jossa strukturoitu kirjallinen materiaali esitetään av-tekniikan avulla, usein tosin jo kaksisuuntaisena. Kolmas polvi, joka hyödyntää täysimittaisesti tieto- ja informaatiotekniikkaa, odottaa vielä tulemistaan.

K un koulutus pysyy keskeisenä tuotannolli1 sena ja yhteiskunnallisena tekijänä ja kun koulutustaso jatkuvasti nousee - onhan työvoimastamme jo runsaat kymmenen prosenttia korkeakoulutettuja ja osuus suurten ikäluokkien alkaessa poistua työmarkkinoilta erittäin voimak- 
kaasti nousee - olettaisi, että korkea-asteen täydennyskoulutukseen ja avoimeen korkeakouluun olisi uhrattu runsaastikin koulutussuunnittelun kapasiteettia.

Onhan aikuiskoulutuksen tiimoilta 70-luvun alusta istunut koko joukko komiteoita ja työryhmiä. Suoranaisesti avointa korkeakoulua käsitteleviä sen sijaan ei juurikaan ole ollut. Ensimmäinenhän oli Suomen kulttuurirahaston asettama 1976 ja seuraava mietintö ilmestyi 1981 ja sen pohjalta valtioneuvoston ohjeet avoimen korkeakoulun suunnittelusta ja järjestämisestä. Näiden mukaan toiminnan puitteet ovat sitten paljolti ovat.

Onnettominta näissä on ollut avoimen korkeakoulun määrittely ja vastuun jako. Toiminta on ymmärretty täydennyskoulutukseksi ja väljätavoitteiseksi sivistysharrastukseksi, siis jonkinlaiseksi kansalaisopistojen harrastustoiminnaksi, ja sen asema on nähty osana korkeakoulujen täydennyskoulutusta. Korkeakoulujen taloussuunnittelussa sitä pidetään kuitenkin jonkinlaisena huutolaispoikana ja välttämättömänä pahana, joka elääkin epävarman vuosittaisen subventioalmun varassa. AKK:n toimikunnan positiivisista esityksistä tärkeimmät ovat toteutumatta, esimerkiksi valtakunnallinen kattava ja koordinoitu etäopetustarjonta ja siihen liittyvä lähiopetus, joista olisi rakennettavissa australialaisen mallin mukainen ekstensioyliopisto. Varsinainen avoimen korkeakoulun neuvottelukunta puuttuu edelleenkin. Ehdotetut korkeakoulujen AKKkeskukset ovat supistuneet muutamiksi suunnittelijoiksi täydennyskoulutuskeskuksiin. Kustannusjaosta valtion, kuntien ja opiskelijoiden kesken ei ole päästy järkeviin ja väistämättä edessä oleviin ratkaisuihin.

Itse liittäisin työnantajan mukaan tavalla tai toisella kantamaan osansa kustannuksista. Muuttuvassa maailmassa on kestämätöntä pitää erillään yleissivistävää ja ammatillista (täydennys)koulutusta. Mutta inhimillisen pääoman teorian mukaan koulutus tuottaa myös katetta yksilölle, ja hänen koulutuskustannuksensa ovat siis investointia tuon hyödyn saamiseksi. Tuntuu luonnolliselta, että hyödyn saaja itse on ainakin osaksi vastuussa investoinneista, ts. olisi valmis tinkimään tämän hetken kulutustasostaan tulevaisuudessa saatavan suuremman hyödyn vuoksi. Mutta miksi AKK:n opiskelijan olisi suoritettava osa koulutuskustannuksista, kun tiedekunnan opiskelijakaan ei sitä tee? Vainko sen vuoksi, että hän on jaksottanut opiskelun ja työn toisella tavalla?

Mm. aikuiskoulutuksen opintososiaalinen toi48 mikunta (1983), korkeakoulujen opiskelijavalin- tatoimikunta (1986) ja kesäyliopistotoimikunta (1988) ovat sivunneet mietinnöissään myös avointa korkeakoulua. Mutta yllättävää ja kuvaavaa on, että opetusministeriön kohuvisiossa peruskoulun jälkeisen koulutuksen kehittämisestä ja sen pohjalta laaditussa jatkomietinnössä ei lainkaan mainita avointa korkeakoulua (ainoa kommentti: AKK:ta on laajennettava) ja aikuiskoulutuksestakin puhutaan yleispätevin latteuksin! Jatkuvan koulutuksen komitea (1983) antaakin kattavimman ideologisen perustan myös avoimelle korkeakoululle, mutta sen ohjelmanjulistus on jäänyt täysin operationalisoimatta. Komitean perusideahan oli, että koulutusjärjestelmän sisäistä yhteistyötä kehittämällä ja järjestelmän ulkopuolisia toimintoja opinnollistamalla luodaan todellien avointen opintojen järjestelmä. Yleensä avointa korkeakoulua perustellaan koulutuksen tasa-arvoistamisella, toisen mahdollisuuden antamisella. Tavoite on luonnollisesti kannatettava vieläkin, mutta sen sisältö pitäisi muuttaa. Toimintahan on lähtenyt kulttuurin demokratisoimisen periaatteesta: kaikkilla pitää olla mahdollisuus jakaa myös korkeakoulusivistyksen kautta saatavilla oleva eliitin kulttuuripääoma. Euroopan neuvosto katsoo, että tähän ei heterogeenisessa väestössä ja pluralistisessa kulttuurissa pidä tyytyä, vaan on pyrittävä demokraattiseen kulttuuriin, ts. korkeakulttuurista monikulttuuriseen malliin. Silloin korkeakouluopintojen sisältö voi samankin oppiaineen sisällä vaihdella huomattavasti. Kysymyshän on lähinnä opetuksen ja vaatimusten tasosta.

K orkeakoulutuksen tulee olla kasvattavaa. Ja kasvatuksen päämääränä on kehittää ihmisen kykyä hallita omaa elämäänsä ja niitä sosiaalisia, kulttuurisia ja taloudellisia ehtoja, jotka hänen elämäänsä vaikuttavat.

Jos koulutuksen pitäisi tehdä ihmisestä autonominen ja itseensä luottava persoona, on hänellä myös oltava sananvaltaa omaa koulutustaan koskevassa päätöksenteossa. Meiltä kuitenkin puuttuu edunvalvonta- ja osallistujayhteisö, jota voisi kutsua avoimen korkeakoulun opiskelijakunnaksi. Ja kun sellaista ei ole, ei ole myöskään avoimen korkeakoulun opiskelijan identiteettiä.

Avoin korkeakoulu on korkea-asteen aikuiskoulutusta. On siis kaksikin syytä, miksi sen opiskelijat pitäisi huomattavasti aktiivisemmin saada mukaan koulutuksen suunnitteluun. Asiakkaista lähtevä suunnittelu saisi aikaan, että opintojen tasosta ja vaativuudesta tinkimättä tavoitteet ja sisällöt voitaisiin määritellä koulutusohjelmista poikkeavasti. Tiedostava ja valveutunut opiskelijakunta on edellytys omaleimaisen avoimen korkeakoulun muodostumiselle. Sellais- 
tahan Suomessa ei vielä ole - monen mielestä ei omana organisaationa tarvitakaan - on vain hallinnollisesti määritelty korkeakouluopetuksen tarjonnan muoto.

Rakentava tapa päästä eteenpäin koulutuksen suunnittelussa on eksplikoida tarjoajien ja kysy- jien olettamukset ja tarpeet. On tunnistettava millaiseksi opiskelija ymmärretään ja mitkä hänen opiskelumotiivinsa ovat. Näistä voitaisiin rakentaa ristiintaulukoita ja katsoa miten kattavaan palveluun voimavarat riittävät. Vaikkapa seuraavasti:

\section{Taulukko 1:}

Avoimen korkeakoulun kysynnän ja tarjonnan logiikan yhteensovittaminen

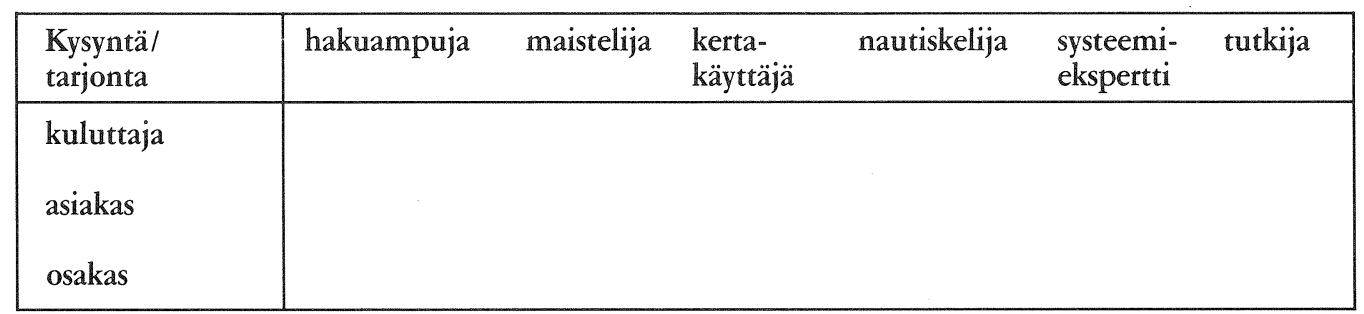

Kuluttajamallissa avoin korkeakoulu tarjoaa tuotteita odottavalle yleisölle, jonka tarpeista markkinointitutkimus on ottanut selvän. Selvää on, että koulutushyödykkeistäkin maksetaan täysi, jopa kaupallinen hinta. Tarjoaja saa kuitenkin varautua siihen, että käyttäjien kulutustottumukset vaihtelevat. Asiakasmallissa opiskelija joutuu riippuvuuteen kouluttajan professionalisesta asiantuntemuksesta, jolloin häneltä evätään mahdollisuus arvioida koulutuksensa laatua. Valta määritellä tarjonnan muodot ja sisällöt on koulutuksen tarjoajalla. Osakasmallissa opiskelija on osittaisessa taloudellisessa ja suunnitteluvastuussa oppimisestaan ja hänellä on päätösvaltaa opiskelun muodoista ja sisällöistä.

Osa opiskelijoista toimii hakuampujina. Haetaan ajankulua ja mielenkiintoisia kokemuksia. Halutaan katsoa, mihin kannattaa ryhtyä. Mais- telija valikoi tarkoin. Hän osallistuu vain sellaiseen, joka hänelle sopii ja silloin kun se sopii. Kertakäyttäjä etsii ratkaisua spesifiin ongelmaan. Kun se on löytynyt, mielenkiinto sammuu ja jo opittu unohtuu. Nautiskelija haluaa korkeakoulusivistystä sen itseisarvon vuoksi ja tarttuu tarjottuun 'toiseen mahdollisuuteen". Systeemiekspertti on sisäistänyt koulutuksen väline- ja vaihtoarvon. Hän osaa käyttää tarkoin hyväkseen järjestelmän tarjoamat sosiaaliset ja koulutukselliset edut edetäkseen urallaan. Tutkija etsii haasteita ja välineitä vastatakseen noihin haasteisiin.

Tähänastista avoimen korkeakoulun tarjontaa on hallinnut yhdistelmä asiakas-kuluttaja/ hakuampuja, maistelija. Tästä puolestaan voisi vetää johtopäätöksen, että suurta osaa potentiaalista opiskelijakuntaa avoimen korkeakoulun tarjonta ei vielä kohtaa.

\section{REIJO RAIVOLA}

